Review

\title{
Sex-Related Predisposition to Post-Traumatic Stress Disorder Development-The Role of Neuropeptides
}

\author{
Małgorzata Lehner ${ }^{1}$, Anna Skórzewska ${ }^{1}$ (D) and Aleksandra Wisłowska-Stanek ${ }^{2, *}$ \\ 1 Department of Neurochemistry, Institute of Psychiatry and Neurology, 9 Sobieskiego Street, \\ 02-957 Warsaw, Poland; mlehner@ipin.edu.pl (M.L.); skorzews@ipin.edu.pl (A.S.) \\ 2 Centre for Preclinical Research and Technology (CEPT), Department of Experimental and Clinical \\ Pharmacology, Medical University of Warsaw, 1B Banacha Street, 02-097 Warsaw, Poland \\ * Correspondence: awislowska@wum.edu.pl; Tel.: +48-22-116-6160
}

Citation: Lehner, M.; Skórzewska, A.; Wisłowska-Stanek, A. Sex-Related Predisposition to Post-Traumatic Stress Disorder Development-The Role of Neuropeptides. Int. J. Environ. Res. Public Health 2022, 19, 314.

https://doi.org/10.3390/

ijerph19010314

Academic Editor:

Agata Faron-Górecka

Received: 14 October 2021

Accepted: 24 December 2021

Published: 28 December 2021

Publisher's Note: MDPI stays neutral with regard to jurisdictional claims in published maps and institutional affiliations.

Copyright: (c) 2021 by the authors. Licensee MDPI, Basel, Switzerland. This article is an open access article distributed under the terms and conditions of the Creative Commons Attribution (CC BY) license (https:// creativecommons.org/licenses/by/ $4.0 /)$.

\begin{abstract}
Post-traumatic stress disorder (PTSD) is characterized by re-experiencing a traumatic event, avoidance, negative alterations in cognitions and mood, hyperarousal, and severe functional impairment. Women have a two times higher risk of developing PTSD than men. The neurobiological basis for the sex-specific predisposition to PTSD might be related to differences in the functions of stress-responsive systems due to the interaction between gonadal hormones and stress peptides such as corticotropin-releasing factor (CRF), orexin, oxytocin, and neuropeptide Y. Additionally, in phases where estrogens levels are low, the risk of developing or exacerbating PTSD is higher. Most studies have revealed several essential sex differences in CRF function. They include genetic factors, e.g., the CRF promoter contains estrogen response elements. Importantly, sex-related differences are responsible for different predispositions to PTSD and diverse treatment responses. Fear extinction (the process responsible for the effectiveness of behavioral therapy for PTSD) in women during periods of high endogenous estradiol levels (the primary form of estrogens) is reportedly more effective than in periods of low endogenous estradiol. In this review, we present the roles of selected neuropeptides in the sex-related predisposition to PTSD development.
\end{abstract}

Keywords: PTSD; sex differences; CRF; orexin; oxytocin; neuropeptide Y

\section{Introduction}

Post-traumatic stress disorder (PTSD) is a mental health condition triggered by a traumatic event [1,2]. Symptoms of PTSD are re-experiencing trauma, avoidance of traumaassociated stimuli, general anxiety, emotional numbing, and hyperarousal [3]. The key feature of this disorder is impaired extinction (defined as a decrease in the frequency and amplitude of conditioned responses) and enhanced emotional memory consolidation during trauma. The pathophysiology of PTSD is associated with enhanced feedback sensitivity of the hypothalamic-pituitary-adrenal (HPA) axis, hypersecretion of corticotropin-releasing factor (CRF), subnormal cortisol levels (hypocortisolemia), and noradrenergic hyperactivity $[1,4]$.

A critical sex-specific predisposition to the occurrence of PTSD has been identified. Women have a two times greater risk of developing PTSD and are more likely to suffer a more chronic course of the disorder [5-9]. Sex differences in PTSD prevalence are evident even when men and women experience the same type of trauma, such as accidents, terrorism, and natural disasters [7,9]. Moreover, epidemiological studies suggest that women may have a higher risk for developing PTSD or exacerbating their present symptoms during phases of their lives, when estrogen levels are low: puberty, menses, postpartum, and menopause [10]. In addition, women who experienced the initial trauma during the luteal phase (low estrogen levels) reported more significant difficulties with flashbacks [11]. Researchers have hypothesized that the higher prevalence of PTSD in women may be a 
consequence of estrogen-related differences in neuroendocrine and stress response systems [12]. Moreover, the functional magnetic resonance (fMRI) that indicates that stressful events would cause a greater increase in the arousal network (e.g., locus coeruleus (LC) and periaqueductal gray) of women than men following exposure to aversive (threat) stimuli probably due to different sensitivity of these structures depending on the estrogen concentration [13].

Considering that the stress response is variable and depends on the changes in hormones concentration, in this review, we focus on the role of selected hypothalamic hormones in the estrogen dependent predisposition, course, and treatment of PTSD in females. The major regulator of the HPA axis is a corticotropin-releasing factor, the pituitary hormone adrenocorticotropic hormone $(\mathrm{ACTH})$, and the negative feedback effects of adrenal glucocorticoids, but other hypothalamic neuropeptides, including oxytocin, orexin, and neuropeptide $\mathrm{Y}$ (NPY) can affect HPA axis activity by influencing the expression and secretion of $\mathrm{CRF}$, modulating pituitary function or adrenal steroidogenesis. Hypothalamic peptides and the HPA axis reciprocally control each other's activities; moreover, gonadal hormones could affect their function. The interaction between sex hormones, the HPA axis, and hypothalamic hormones is complex and occurs on both genetic-by controlling the expression of peptides via interaction with gene promotors-and epigenetic levels. Patients with PTSD exhibit an altered balance between excitatory (CRF and orexins) and anti-stress hormones (oxytocin and NPY) $[5,14,15]$. In this review, we decided to introduce this poorly explored problem.

\section{Hypothalamic Stress Neuropeptides}

\section{1. $C R F$}

$\mathrm{CRF}$ is a neuropeptide released from the paraventricular nucleus of the hypothalamus (PVN) that activates the HPA axis and regulates stress-related behaviors. CRF stimulates the secretion of adrenocorticotropic hormone, which acts on the adrenal cortex to produce glucocorticoids (e.g., cortisol in humans and primates and corticosterone in rodent species) [16-18]. Via GR (glucocorticoid) and MR (mineralocorticoid) receptors, glucocorticoids regulate negative feedback to the HPA axis by inhibiting the release of CRF and ACTH. Moreover, CRF centrally modulates the activity of various brain regions (hippocampus, amygdala and locus coeruleus) that regulate behavioral responses to stress and cognitive function [19-21]. Increased cerebrospinal fluid CRF concentrations have been reported in patients with PTSD [16-18].

Most studies have revealed several essential sex differences in CRF function. Preclinical and clinical data suggest greater sensitivity of CRF neurons in regions of the hypothalamus and bed nucleus of the stria terminalis (BNST) in female rats than in male rats to environmental stress and corticosterone levels [21-24]. Different predispositions to stress-related psychiatric disorders might be partially attributed to interactions between gonadal hormones and stress hormones $[25,26]$. Estrogens enhance activation of the CRF gene in stress. Estradiol also regulates CRF binding protein (CRF-BP) mRNA expression and increases the excitability of CRF neurons in the PVN [27]. Evidence suggests that in animal models (primates and rats), the HPA axis of females is more sensitive than that of males to the effects of higher levels of CRF during phases of the estrous cycle characterized by high ovarian hormone levels. Moreover, gonadal hormones have an important role not only in adult individuals but also in the perinatal period, as estradiol and testosterone exposure organizes sex differences in the CRF system in PVN [28]. The structures containing CRF receptors are also characterized by the presence of estrogen receptors; thus, gonadal hormones are potentially able to regulate CRF receptors [29]. For example, estrogen treatment significantly increased CRF mRNA expression in the amygdala and the BNST of ovariectomized mice [30,31]. Estrogen increases the expression of CRF1 and CRF2 in breast cancer cells [32] and probably in the brain [33]. Many estrogen effects are mediated by estrogen receptors (ER) that bind to specific estrogen response elements (EREs) in target promoters [26,31]. The CRF promoter contains EREs; therefore, it is assumed that estrogen 
may directly affect CRF gene expression [34]. Several studies have documented decreased CRF mRNA expression in the PVN of ovariectomized animals and its restoration after estradiol replacement treatment, suggesting a stimulatory effect of estrogen on CRF [34-37].

CRF action is mediated by CRF1 and CRF2 receptors. Evidence for sex differences in CRF receptor expression, distribution, trafficking, and activation in brain regions that might be associated with different predispositions to PTSD has been reported $[25,38]$. In the cingulate cortex and amygdala, CRF1 receptor binding is higher in adult female rats. In comparison, CRF2 receptor binding is higher in the amygdala and the hypothalamus in male rats [39]. This distribution is probably related to an increase in anxiety-like behaviors in females under stress compared to males [5].

Studies have revealed that stress-induced increases in CRF levels contribute to neuropsychiatric disease development through the excess activation of its type 1 receptor [40]. Moreover, pharmacological antagonism of CRF1 suppresses the stress response and decreases anxiety- and depressive-like behaviors [41]. Importantly, pharmacological intervention might exert an anti-anxiety effect, but some internal homeostatic processes, such as receptor trafficking, potentially attenuate the stress response and anxiety. These processes are sex-specific and occur in the locus coeruleus. Data suggest that the higher predisposition of women to PTSD might result from stronger activation of the locus coeruleus by CRF than in men. LC neurons are protected from the effects of excessive CRF by internalizing CRF1 receptors [42]. Females have greater activation of LC circuits, which may be associated with the decreased internalization of CRF1 receptors under stress conditions compared to males [25,38].

\subsection{Orexin}

Orexins (ORX), which are also called hypocretins, are excitatory neuropeptides involved in the neuroendocrine response to stress, arousal, food intake, cognitive flexibility, sleep control, emotional memory, and reproduction $[43,44]$. Both stressful stimuli and CRF increase orexin neurons activity $[45,46]$. The orexin system is composed of endogenous neuropeptides, orexin $A$ and $B$, and associated orexin type 1 and 2 receptors (OX1R and OX2R, respectively) [47]. Orexins are synthesized in the hypothalamus, while orexin receptors are widely distributed in the brain. OX1R receptors are expressed in the cingulate cortex, the hippocampus, BNST, and amygdala [48]. Orexins are presumed to be involved in cognitive functions via stimulation of pyramidal neurons in the prefrontal cortex and dentate gyrus of the hippocampus [48,49]. ORX A administration into the hippocampus reverses memory disruption under conditions of orexin deficiency [50]

\subsection{Dysfunction of the Orexin System Has Been Reported in PTSD}

A correlation study suggested that high ORX A levels in plasma were associated with spontaneous recovery of recent memory after extinction [51,52]. In particular, ORX expressed in the amygdala might be the target of fear memory and anxiety disorders [53]. During acute stress, orexin increases HPA activity and promotes the neuroendocrine response. In contrast, repeated stress involves more complex mechanisms contingent on the type, intensity, and duration of the stimuli, which indicate the inherent plasticity of the orexin system [54].

Preclinical and clinical data highlight sex differences in the orexin system, as female rats showed higher baseline levels of orexin precursor prepro-orexin mRNA, orexin neuron activation (measured as c-Fos immunoreactivity) in the hypothalamus, and orexin A levels in the cerebrospinal fluid than male rats [55]. Elevated orexin levels in female rats are responsible for the increased HPA responses to repeated stress and the stress-induced impairments in cognitive flexibility [55]. The literature suggests that gonadal hormones might be involved in the sex-specific interaction between the HPA axis and orexin [55]. Regulation of orexin expression in female rats depends on their reproductive status. Studies have indicated that female rats display higher prepro-orexin mRNA levels during proestrus (high level estrogen phase), but ovariectomized females showed no reduction in prepro-orexin 
mRNA expression [56]. Moreover, in women, plasma orexin levels increase significantly during menopause [57].

Studies have reported increase in OX1R and OX2R expression in the PVN of female rats [58]. Orexins regulate the stress response by increasing ACTH release from the pituitary through OX1R and OX2R receptors and stimulating glucocorticoid release via OX1R in the adrenal gland [59-61]. In the chronic unpredictable mild stress model, a significant increase in OX1R expression was observed in the frontal cortex of female rats, but not male rats [62]. In the PVN, glucocorticoid receptors act directly on the orexin promoter to increase prepro-orexin expression, providing a regulatory mechanism that exclusively controls orexin system activity in females [55].

\section{Anti-Stress Hormones}

\subsection{Oxytocin}

Oxytocin (OT) is a neuropeptide synthesized in the hypothalamus. In addition to the classical functions of oxytocin, such as inducing uterine contractions during labor and milk ejection during nursing, it regulates stress coping behaviors through its anxiolytic action, which is essential for maternal behavior and social bond formation [63,64]. Neuronal projections from the hypothalamus send oxytocin to the posterior pituitary gland. In humans, oxytocin affects the central and basolateral amygdala, hippocampus, cingulate cortex, olfactory nucleus, and brainstem, regions expressing oxytocin receptors. The oxytocin and HPA axis are mutually regulating systems. Oxytocin inhibits the stressinduced activity of the HPA axis by promoting the return of cortisol levels to normal after stress is experienced [65]. OT has also been shown to decrease the activity of limbic regions that project to hypothalamic and brainstem regions and thus attenuate the fear response [66-68].

Stressful experiences might alter the function of the hypothalamus by decreasing the synthesis and release of endogenous OT [69]. Human studies suggest that outpatients with PTSD, both male and female, have reduced plasma oxytocin levels compared to healthy controls [70]. A reduced level of OT indicates decreased resiliency to stress [71]. Clinical trials with small samples suggest therapeutic effects of oxytocin administration on patients with PTSD [72,73]. Frijling [72] found that intranasal administration of oxytocin is a promising early preventive intervention for PTSD in individuals with an increased risk of PTSD. Oxytocin promotes fear extinction favoring better emotional control and enhanced cognitive performance by reducing hypervigilance, avoidance, and anhedonia [72,73].

Preclinical evidence indicates that OT expression differs in various brain structures (e.g., forebrain and hypothalamus) between males and females [74,75]. Moreover, the oxytocin promoter is regulated by estrogen [76]. Oxytocin disturbances are particularly associated with PTSD psychopathology in postpartum women [14,77]. Estrogen increases OT receptor expression and the release of this hormone, whereas androgens inhibit the release of OT under stress [78-80]. Sex effects might involve the differences in the number and binding affinity of OT receptors in specific neural networks [74].

\subsection{Neuropeptide $Y$}

Neuropeptide Y (NPY) regulates food intake, energy homeostasis, circadian rhythm, and cognition and has anxiolytic properties. High NPY expression is observed in the hypothalamus, septum, nucleus accumbens, periaqueductal grey, and LC [15]. Research indicates that the stress-protective effects of NPY are mediated by modulating neurotransmission in the amygdala, hippocampus, and cerebral cortex. NPY attenuates the stress-induced increase in the expression of norepinephrine biosynthetic enzymes and CRF release [81,82]. NPY neurons innervates ORX containing cells in the lateral hypothalamus [83]. NPY deficiency may upregulate ORX, activate noradrenergic neurons, and evoke heightened arousal [84]. Lower levels of NPY in the plasma and cerebrospinal fluid are associated with PTSD [85]. In preclinical studies, anxiolytic effects and improved 
fear extinction were documented after an intracerebroventricular (ICV) administration of NPY [86].

According to previous studies, NPY concentrations in the brain exhibit a sex-dependent pattern, with lower levels detected in female rats than in male rats under basal and stressed conditions [15]. In females, lower levels of the NPY peptide and lower expression of its receptor Y1R were observed in the hypothalamus, striatum, hippocampus, and plasma than in male rats. The lower expression of NPY in the hypothalamus might contribute to the increased activation of the HPA axis, resulting in greater susceptibility to stress-related disorders in females [15]. Additionally, the literature suggests a sex-specific difference in the expression of NPY receptor. Females have lower Y1R expression but higher Y1R-NPY binding affinity in the cerebral cortex than males [87]. Nahvi et al. [88] found that Y1R and CRFR1 mRNA levels increased in the LC of female rats compared with unstressed control rats 1 week or more after exposure to a single prolonged stress (PTSD model). In females, Y1R receptors appear to attenuate the effects of CRF1 receptors. Furthermore, no changes in Y1R expression were found in males, suggesting the potential importance of these receptors in females $[15,82]$. Estrogen contributes essentially to the regulation of Y1R expression because its gene contains of estrogen response elements. Consequently, during the high-estrogen phase (proestrus), an increase in Y1R expression was detected in the hypothalamus compared to other estrous cycle phases $[15,89,90]$. Furthermore, the female to male ratio of PTSD prevalence was highest among adolescents and young adults approximately (3:1) and decreased (2:1) among older adults (66 to 70 years old) [91,92].

In the Table 1 we presented the influence of estrogens and HPA axis on the expression of selected hypothalamic peptides. In the Figure 1 there are presented the differences in the neuropeptides and receptors in brain structures of women or men with PTSD.

Table 1. Influence of estrogens and HPA axis on the expression of selected hypothalamic peptides.

\begin{tabular}{ccc}
\hline Hypothalamic Peptide & Estrogen Influence & HPA Axis Influence \\
\hline CRF & $\begin{array}{c}\text { Increases expression of CRF via } \\
\text { interaction with ERE [45] }\end{array}$ & $\begin{array}{c}\text { Glucocorticosteroids via GR receptors } \\
\text { inhibit CRF expression [93] }\end{array}$ \\
\hline CRF1 and CRF2 receptors & Increases expression [33] & $\begin{array}{c}\text { High CRF level decreases expression of } \\
\text { CRF receptors (down-regulation) [94] }\end{array}$ \\
\hline Prepro-orexin & No data & Increases expression by GR [55] \\
\hline Oxytocin & $\begin{array}{c}\text { Increases expression through action on } \\
\text { oxytocin gene promoter [76] } \\
\text { Deuropeptide Y }\end{array}$ & No data \\
\hline Neupopeptide Y receptors Y1R & $\begin{array}{c}\text { Increases expression via interaction } \\
\text { with ERE [89] }\end{array}$ & No data \\
\hline
\end{tabular}

HPA—hypothalamic-pituitary-adrenal; ERE—estrogen response element; GR—glucocorticoid receptors, CRFcorticotropin releasing factor, CRF1, CRF2-CRF receptors type 1 and 2. 


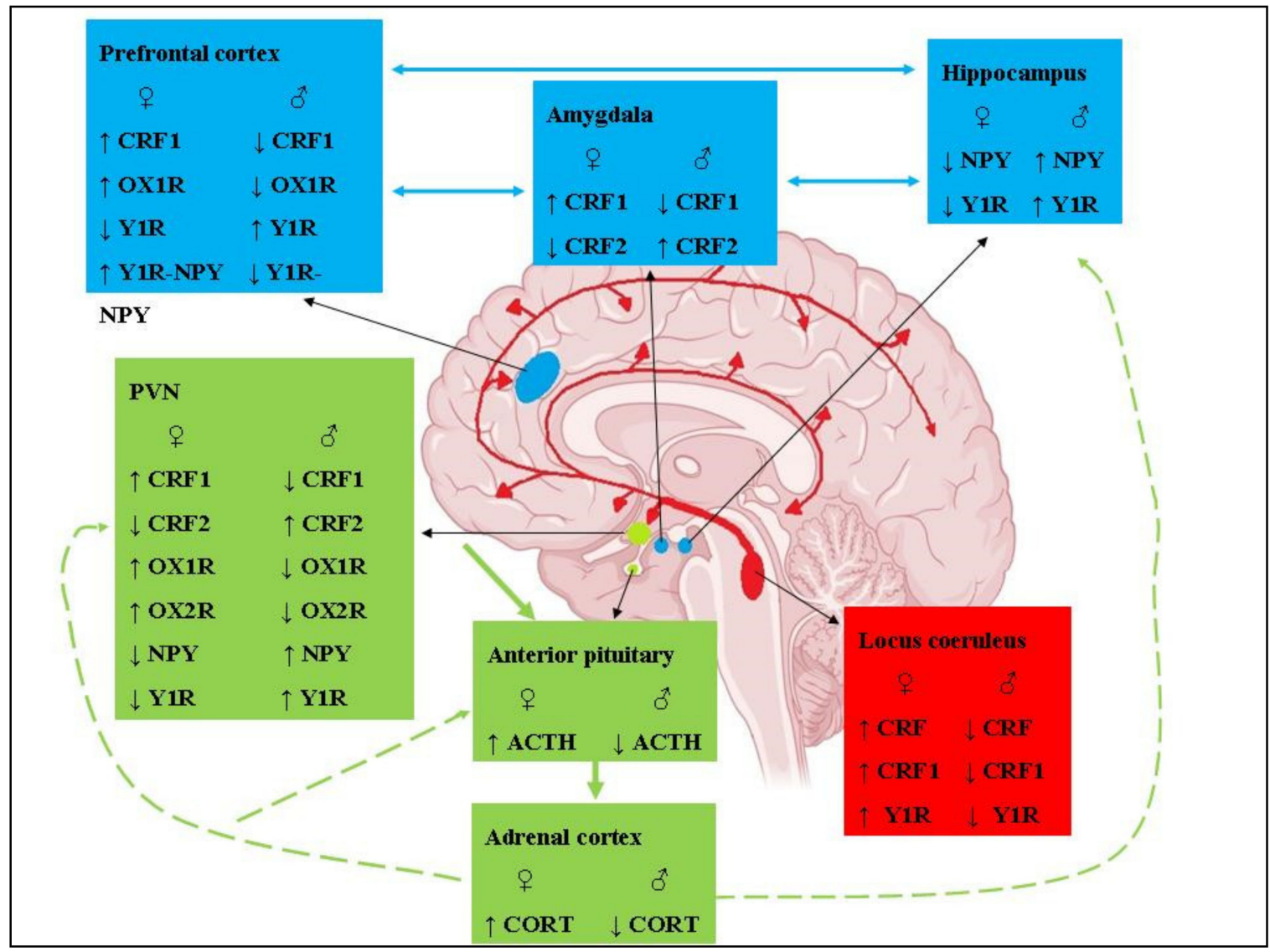

Figure 1. Changes in the activities of neuropeptides and their receptors in brain structures regulating cognition and the stress response that are responsible for the development of PTSD in women compared to men. The corticolimbic circuitry that mediates emotional responses to negative stimuli is shown in blue. The locus coeruleus norepinephrine system that initiates arousal responses to stress is shown in red. The HPA axis that regulates the neuroendocrine responses to stress is shown in green. Negative feedback (marked with green lines) is reduced in females and may further increase the release of glucocorticoids. \&-females; 8 -males; ACTH-adrenocorticotropic hormone; CORT-cortisol; CRF- corticotropin-releasing hormone; CRF1, CRF2-CRF receptors type 1 and 2; OX1R, OX2R-orexin receptors type 1 and 2; NPY—neuropeptide Y; Y1R-NPY receptor type 1; Y1R-NPY—binding of NPY to the Y1R receptor, $\uparrow$-increase; $\downarrow$-decrease. The figure was adapted from Matchett et al. [95]. The permission has been obtained and there is no copyright issue.

Table 1 shows influence of estrogens and HPA axis on the expression of selected hypothalamic peptides, Table 2 shows interaction between hypothalamic peptides. Figure 1 shows changes in neuropeptides' activity and their receptors in the brain.

Table 2. Interaction between hypothalamic peptides.

\begin{tabular}{cccc}
\hline CRF & Orexin & Oxytocin & Neuropeptide Y \\
\hline $\begin{array}{c}\text { Activates orexin neurons in } \\
\text { hypothalamus [46] }\end{array}$ & $\begin{array}{c}\text { Increases ACTH release } \\
\text { in pituitary. } \\
\text { Increases glucocorticoid in } \\
\text { adrenal gland [59-61] }\end{array}$ & $\begin{array}{c}\text { Inhibits HPA axis [65] } \\
\text { Inhibits oxytocin release [69] }\end{array}$ & $\begin{array}{c}\text { Contradictory data } \\
\text { decreases CRF release [81], } \\
\text { activates CRF [96] }\end{array}$ \\
\hline No data & $\begin{array}{c}\text { Activates NPY neurons in the } \\
\text { hypothalamus [98] }\end{array}$ & No data & Inhibits orexin neurons [83] \\
\hline
\end{tabular}

CRF-corticotropin-releasing factor, ACTH-adrenocorticotropic hormone, HPA-hypothalamic-pituitaryadrenal, NPY—neuropeptide Y. 


\section{Epigenetic Changes}

Epigenetics is a sequence-independent heritable DNA change that may be triggered by environmental factors [100]. Epigenetic mechanisms include DNA methylation, histone modifications, nucleosome repositioning, higher-order chromatin remodeling, noncoding RNAs (microRNAs), and RNA and DNA editing [101]. Some epigenetic modifications occur in a sex-specific matter and might be associated with a predisposition to PTSD [102]. Preclinical studies showed that in the model of chronic mild stress, stressed females had a higher level of total DNA methylation across the CRF gene in the PVN than stressed males [102]. Moreover, some epigenetic changes are potential biomarkers of disease or are valuable for monitoring treatment, e.g., the response of individuals with PTSD to treatment is associated with decreases in the methylation of FKBP5 (FK506-binding protein 5, the protein that binds to and inhibits glucocorticoids) [4]. Interestingly, studies of the offspring of Holocaust survivors indicate that maternal PTSD has a more significant contribution than paternal PTSD to an increased risk of PTSD, probably due to epigenetic mechanisms [103].

MicroRNAs, critical regulators of gene expression involved in neuronal development, synapse formation, and synaptic plasticity, have also been linked to the regulation of neurobiological systems underlying anxiety processing in PTSD [104,105]. MicroRNAs are a class of small noncoding RNAs that mediate cleavage or translational repression of target mRNAs [106]. The binding of microRNAs decreases the stability of target mRNAs or inhibits their translation to downregulate mRNA expression [107]. A potential role for miR-19b in regulating genes associated with delayed and exaggerated fear was reported [108]. Previous data showed that miR-19b was under the transcriptional control of the estradiol [109]. Male animals exposed to single prolonged stress exhibited higher levels of circulating miR-19b than control male animals. In turn, female animals exposed to unpredictable sound stress displayed lower levels of miR-19b compared with control female animals [109]. Translational research approaches identified miR-19b as a potential marker for PTSD that is differentially expressed in males and females after trauma or stress. In a clinical study, the miR-144-5p expression levels in the blood plasma of patients suffering from depression/anxiety were lower than those in healthy controls [110]. Interestingly, miR-144-5p increased to levels observed in healthy controls following eight weeks of psychotherapy, suggesting that miR-144-5p might be a potential biomarker of treatment success [105]. Additionally, miR-138-5p was overexpressed in subjects with PTSD compared to controls, and miR-1246 was downregulated in patients with PTSD compared to resilient subjects. These findings suggest that these microRNAs might be potentially relevant to diagnosing PTSD [111].

\section{PTSD Therapy in Women}

According to the data, less than 50\% of individuals with PTSD remit spontaneously [4]. In the treatment of PTSD, the most important and well-established role has been identified for psychological therapies with (or without) pharmacological support. These treatments reduce symptoms severity [4]. The known predictor of exposure therapy is fear extinction. This process depends on the acquisition of new inhibitory learning, where fear memory is weakened by the successive presentation of a fear-eliciting conditioned stimulus without an aversive stimulus [112]. Fear extinction involves the weakening (long-term depression) of previously potentiated synapses [113]. Fear processes and fear extinction are strongly regulated by circulating sex hormones; however, the specific effects of sex hormones on fear extinction remain poorly understood [114].

Both preclinical and clinical studies suggest that fear extinction depends on the estrogen levels $[115,116]$. Neuroimaging studies show greater activation of neural networks involved in fear induction during the early follicular phase of the menstrual cycle (low estrogen levels) compared to mid-cycle (high estrogen levels) [117]. However, female rats subjected to conditioning in the proestrus and estrus stages (high estrogen levels) extinguished fear more rapidly than male rats and female rats in the diestrus stage (low estrogen levels) [118]. Additionally, a high level of estrogen protected against the extinction deficit 
observed in women with PTSD [119]. Studies in both humans and animals support this observation by showing that low estrogen levels are associated with deficits in fear extinction recall compared with phases characterized by higher estrogen level. Psychotherapy based on fear extinction is more effective in women during periods with high endogenous estradiol levels than in periods with low endogenous estradiol levels or the administration of hormonal contraceptives [120,121]. Thus, an analysis of exposure therapy in women using hormonal contraception seems very important. This behavioral effect might be associated with the effects of estrogens on the transcription of peptides that control the function of the HPA axis and play an important role in fear extinction, such as CRF and NPY.

In patients with more severe cases of PTSD, when psychotherapy alone is insufficient to achieve remission, selective serotonin reuptake inhibitors (SSRIs) are used. Only two medications are currently approved by the US Food and Drug Administration (FDA) for treating PTSD: paroxetine and sertraline [121]. SSRIs increase the expression of NPY in the brain, and this mechanism is related to fear extinction [122]. Hormonal fluctuations may modulate the activity of neuronal circuits relevant for fear extinction. Interestingly, a recent clinical trial that tested the effects of intranasal NPY on patients with PTSD found sex differences in response to this treatment. Women require higher doses of NPY than men to achieve a therapeutic effect [123].

Sleep disturbances are one of the most commonly reported and refractory symptoms of PTSD that might hamper the treatment of this disorder [124]. Studies focusing on traumarelated sleep disturbances in women are limited. They have shown therapeutic effects of cognitive-behavioral therapy for insomnia, imagery rehearsal therapy, or combinations of these techniques on sleep quality, insomnia, and nightmare severity in trauma-exposed patients [125]. Limited evidence also suggests the positive effects of drug-assisted psychotherapy with D-cycloserine, a partial agonist of the N-methyl-D-aspartate receptor, by enhancing extinction learning and attenuating insomnia severity [126].

\section{Conclusions}

PTSD is a mental disorder associated with the impaired extinction of traumatic episodes. PTSD occurs twice more frequently in women than in men. Additionally, epidemiological studies suggest that women may have a higher risk of developing or exacerbating PTSD during the phases of their lives when estrogen levels are low, such as puberty, menses, postpartum, and menopause [10]. The neurobiological basis of sex-related susceptibility to PTSD is associated with differences in the functioning of the HPA axis and hypothalamic neuropeptides that are partially dependent on estrogens. These sex differences in CRF system activity are partially attributed to circulating ovarian hormone levels because the CRF promotor contains estrogen response elements. Moreover, males and females exhibit differences in the expression of CRF1 and CRF2 receptors in the LC and limbic structures. CRF also regulates the actions of other neuropeptides that control emotional memories, such as orexin. Dysfunction of the orexin system has been reported in individuals with PTSD. In turn, the oxytocin and NPY expression is reduced in individuals with PTSD. These changes are associated with decreased resiliency in response to stress. Moreover, NPY has been reported to attenuate stress induced increases in the expression of norepinephrine biosynthetic enzymes and the activity of the HPA axis, counteracting the anxiogenic effects of CRF $[81,82]$. Estrogens not only influence the predisposition to PTSD but also affect its treatment. Fear extinction-based psychotherapy was reported to be more effective in women during periods of high endogenous estradiol levels than in periods with low endogenous estradiol levels or after the administration of hormonal contraceptives. This behavioral effect might be associated with the effect of estrogens on the transcription of peptides that control the function of the HPA axis and play an important role in fear extinction, such as CRF and NPY. Additionally, antidepressants that increase the effectiveness of psychotherapies, such as SSRIs alter the expression of hypothalamic neuropeptides, e.g., NPY. 
Author Contributions: Conceptualization, M.L., A.S. and A.W.-S.; writing-original draft preparation, M.L., A.S. and A.W.-S.; writing-review and editing, A.S. and A.W.-S.; funding acquisition, A.S., A.W.-S. All authors have read and agreed to the published version of the manuscript.

Funding: The study was supported by Grant No. 501-40-003-20017 from the Institute of Psychiatry and Neurology in Warsaw.

Institutional Review Board Statement: Not applicable.

Informed Consent Statement: Not applicable.

Data Availability Statement: No new data were created or analyzed in this study.

Acknowledgments: The study was supported by Grant No. 501-40-003-20017 from the Institute of Psychiatry and Neurology in Warsaw. The project was implemented with CePT infrastructure financed by the European Union-The European Regional Development Fund within the operational program “Innovative economy" for 2007-2013.

Conflicts of Interest: The authors declare no conflict of interest.

\section{References}

1. Bangasser, D.A.; Eck, S.R.; Ordoñes Sanchez, E. Sex differences in stress reactivity in arousal and attention systems. Neuropsychopharmacology 2019, 44, 129-139. [CrossRef] [PubMed]

2. de Vries, G.J.; Olff, M. The lifetime prevalence of traumatic events and posttraumatic stress disorder in the Netherlands. J. Trauma. Stress 2009, 22, 259-267. [CrossRef] [PubMed]

3. Lanius, R.A.; Rabellino, D.; Boyd, J.E.; Harricharan, S.; Frewen, P.A.; McKinnon, M.C. The innate alarm system in PTSD: Conscious and subconscious processing of threat. Curr. Opin. Psychol. 2017, 14, 109-115. [CrossRef] [PubMed]

4. Fischer, S.; Schumacher, T.; Knaevelsrud, C.; Ehlert, U.; Schumacher, S. Genes and hormones of the hypothalamic-pituitary-adrenal axis in posttraumatic stress disorder. What is their role in symptom expression and treatment response? J. Neural Transm. 2021, 128, 1279-1286. [CrossRef]

5. Bangasser, D.A.; Wiersielis, K.R. Sex differences in stress responses: A critical role for corticotropin-releasing factor. Hormones 2018, 17, 5-13. [CrossRef]

6. Galovski, T.E.; Blain, L.M.; Chappuis, C.; Fletcher, T. Sex differences in recovery from PTSD in male and female interpersonal assault survivors. Behav. Res. Ther. 2013, 51, 247-255. [CrossRef]

7. Pooley, A.E.; Benjamin, R.C.; Sreedhar, S.; Eagle, A.L.; Robison, A.J.; Mazei-Robison, M.S.; Breedlove, S.M.; Jordan, C.L. Sex differences in the traumatic stress response: PTSD symptoms in women recapitulated in female rats. Biol. Sex Differ. $2018,9,31$. [CrossRef]

8. Rincón-Cortés, M.; Herman, J.P.; Lupien, S.; Maguire, J.; Shansky, R.M. Stress: Influence of sex, reproductive status and gender. Neurobiol. Stress 2019, 10, 100155. [CrossRef]

9. Tolin, D.F.; Foa, E.B. Sex differences in trauma and posttraumatic stress disorder: A quantitative review of 25 years of research. Psychol. Bull. 2006, 132, 959-992. [CrossRef]

10. Maeng, L.Y.; Milad, M.R. Sex differences in anxiety disorders: Interactions between fear, stress, and gonadal hormones. Horm. Behav. 2015, 76, 106-117. [CrossRef]

11. Ravi, M.; Stevens, J.S.; Michopoulos, V. Neuroendocrine pathways underlying risk and resilience to PTSD in women. Front. Neuroendocrinol. 2019, 55, 100790. [CrossRef]

12. Christiansen, D.M.; Berke, E.T. Gender- and Sex-Based Contributors to Sex Differences in PTSD. Curr. Psychiatry Rep. 2020, 22, 19. [CrossRef]

13. Filkowski, M.M.; Olsen, R.M.; Duda, B.; Wanger, T.J.; Sabatinelli, D. Sex differences in emotional perception: Meta analysis of divergent activation. Neuroimage 2017, 147, 925-933. [CrossRef]

14. Shahrokh, D.K.; Zhang, T.Y.; Diorio, J.; Gratton, A.; Meaney, M.J. Oxytocin-dopamine interactions mediate variations in maternal behavior in the rat. Endocrinology 2010, 151, 2276-2286. [CrossRef]

15. Nahvi, R.J.; Sabban, E.L. Sex Differences in the Neuropeptide Y System and Implications for Stress Related Disorders. Biomolecules 2020, 10, 1248. [CrossRef]

16. Baker, D.G.; West, S.A.; Nicholson, W.E.; Ekhator, N.N.; Kasckow, J.W.; Hill, K.K.; Bruce, A.B.; Orth, D.N.; Geracioti, T.D., Jr. Serial CSF corticotropin-releasing hormone levels and adrenocortical activity in combat veterans with posttraumatic stress disorder. Am. J. Psychiatry 1999, 156, 585-588.

17. Bremner, J.D.; Licinio, J.; Darnell, A.; Krystal, J.H.; Owens, M.J.; Southwick, S.M.; Nemeroff, C.B.; Charney, D.S. Elevated CSF corticotropin-releasing factor concentrations in posttraumatic stress disorder. Am. J. Psychiatry 1997, 154, $624-629$.

18. Sautter, F.J.; Bissette, G.; Wiley, J.; Manguno-Mire, G.; Schoenbachler, B.; Myers, L.; Johnson, J.E.; Cerbone, A.; Malaspina, D. Corticotropin-releasing factor in posttraumatic stress disorder (PTSD) with secondary psychotic symptoms, nonpsychotic PTSD, and healthy control subjects. Biol. Psychiatry 2003, 54, 1382-1388. [CrossRef] 
19. Babb, J.A.; Masini, C.V.; Day, H.E.; Campeau, S. Sex differences in activated corticotropin-releasing factor neurons within stress-related neurocircuitry and hypothalamic-pituitary-adrenocortical axis hormones following restraint in rats. Neuroscience 2013, 234, 40-52. [CrossRef]

20. Fox, J.H.; Lowry, C.A. Corticotropin-releasing factor-related peptides, serotonergic systems, and emotional behavior. Front. Neurosci. 2013, 7, 169. [CrossRef]

21. Hupalo, S.; Bryce, C.A.; Bangasser, D.A.; Berridge, C.W.; Valentino, R.J.; Floresco, S.B. Corticotropin-Releasing Factor (CRF) circuit modulation of cognition and motivation. Neurosci. Biobehav. Rev. 2019, 103, 50-59. [CrossRef]

22. Gallucci, W.T.; Baum, A.; Laue, L.; Rabin, D.S.; Chrousos, G.P.; Gold, P.W.; Kling, M.A. Sex differences in sensitivity of the hypothalamic-pituitary-adrenal axis. Health Psychol. 1993, 12, 420-425. [CrossRef]

23. Johnson, E.O.; Kamilaris, T.C.; Carter, C.S.; Calogero, A.E.; Gold, P.W.; Chrousos, G.P. The biobehavioral consequences of psychogenic stress in a small, social primate (Callithrix jacchus jacchus). Biol. Psychiatry 1996, 40, 317-337. [CrossRef]

24. Viau, V.; Bingham, B.; Davis, J.; Lee, P.; Wong, M. Gender and puberty interact on the stress-induced activation of parvocellular neurosecretory neurons and corticotropin-releasing hormone messenger ribonucleic acid expression in the rat. Endocrinology 2005, 146, 137-146. [CrossRef]

25. Bangasser, D.A.; Curtis, A.; Reyes, B.A.; Bethea, T.T.; Parastatidis, I.; Ischiropoulos, H.; Van Bockstaele, E.J.; Valentino, R.J Sex differences in corticotropin-releasing factor receptor signaling and trafficking: Potential role in female vulnerability to stress-related psychopathology. Mol. Psychiatry 2010, 877, 896-904. [CrossRef]

26. Vamvakopoulos, N.C.; Chrousos, G.P. Evidence of direct estrogenic regulation of human corticotropin-releasing hormone gene expression. Potential implications for the sexual dimophism of the stress response and immune/inflammatory reaction. J. Clin. Investig. 1993, 92, 1896-1902. [CrossRef]

27. Hu, P.; Liu, J.; Yasrebi, A.; Gotthardt, J.D.; Bello, N.T.; Pang, Z.P.; Roepke, T.A. Gq Protein-Coupled Membrane-Initiated Estrogen Signaling Rapidly Excites Corticotropin-Releasing Hormone Neurons in the Hypothalamic Paraventricular Nucleus in Female Mice. Endocrinology 2016, 157, 3604-3620. [CrossRef]

28. Patchev, V.K.; Hayashi, S.; Orikasa, C.; Almeida, O.F. Ontogeny of gender-specific responsiveness to stress and glucocorticoids in the rat and its determination by the neonatal gonadal steroid environment. Stress 1999, 3, 41-54. [CrossRef]

29. Weathington, J.M.; Hamki, A.; Cooke, B.M. Sex- and region-specific pubertal maturation of the corticotropin-releasing factor receptor system in the rat. J. Comp. Neurol. 2014, 522, 1284-1298. [CrossRef]

30. Jasnow, A.M.; Schulkin, J.; Pfaff, D.W. Estrogen facilitates fear conditioning and increases corticotropin-releasing hormone mRNA expression in the central amygdala in female mice. Horm. Behav. 2006, 49, 197-205. [CrossRef]

31. Lalmansingh, A.S.; Uht, R.M. Estradiol regulates corticotropin-releasing hormone gene (crh) expression in a rapid and phasic manner that parallels estrogen receptor-alpha and -beta recruitment to a $3^{\prime}, 5^{\prime}$-cyclic adenosine $5^{\prime}$-monophosphate regulatory region of the proximal crh promoter. Endocrinology 2008, 149, 346-357. [CrossRef] [PubMed]

32. Lal, S.; Allan, A.; Markovic, D.; Walker, R.; Macartney, J.; Europe-Finner, N.; Tyson-Capper, A.; Grammatopoulos, D.K. Estrogen alters the splicing of type 1 corticotropin-releasing hormone receptor in breast cancer cells. Sci. Signal. 2013, 6, ra53. [CrossRef] [PubMed]

33. Uribe, K.P.; Correa, V.L.; Pinales, B.E.; Flores, R.J.; Cruz, B.; Shan, Z.; Bruijnzeel, A.W.; Khan, A.M.; O’Dell, L.E. Overexpression of corticotropin-releasing factor in the nucleus accumbens enhances the reinforcing effects of nicotine in intact female versus male and ovariectomized female rats. Neuropsychopharmacology 2020, 45, 394-403. [CrossRef] [PubMed]

34. Ni, X.; Nicholson, R.C. Steroid hormone mediated regulation of corticotropin-releasing hormone gene expression. Front. Biosci. 2006, 11, 2909-2917. [CrossRef] [PubMed]

35. Nappi, R.E.; Bonneau, M.J.; Rivest, S. Influence of the estrous cycle on c-fos and CRH gene transcription in the brain of endotoxin-challenged female rats. Neuroendocrinology 1997, 65, 29-46. [CrossRef] [PubMed]

36. Ogura, E.; Kageyama, K.; Hanada, K.; Kasckow, J.; Suda, T. Effects of estradiol on regulation of corticotropin-releasing factor gene and interleukin-6 production via estrogen receptor type beta in hypothalamic 4B cells. Peptides 2008, 29, 456-464. [CrossRef] [PubMed]

37. Oyola, M.G.; Handa, R.J. Hypothalamic-pituitary-adrenal and hypothalamic-pituitary-gonadal axes: Sex differences in regulation of stress responsivity. Stress 2017, 20, 476-494. [CrossRef]

38. Bangasser, D.A.; Reyes, B.A.; Piel, D.; Garachh, V.; Zhang, X.Y.; Plona, Z.M.; Van Bockstaele, E.J.; Beck, S.G.; Valentino, R.J. Increased vulnerability of the brain norepinephrine system of females to corticotropin-releasing factor overexpression. Mol. Psychiatry 2013, 18, 166-173. [CrossRef]

39. Weathington, J.M.; Cooke, B.M. Corticotropin-releasing factor receptor binding in the amygdala changes across puberty in a sex-specific manner. Endocrinology 2012, 153, 5701-5705. [CrossRef]

40. Howerton, A.R.; Roland, A.V.; Fluharty, J.M.; Marshall, A.; Chen, A.; Daniels, D.; Beck, S.G.; Bale, T.L. Sex differences in corticotropin-releasing factor receptor-1 action within the dorsal raphe nucleus in stress responsivity. Biol. Psychiatry 2014, 75 , 873-883. [CrossRef]

41. Rosinger, Z.J.; Jacobskind, J.S.; Bulanchuk, N.; Malone, M.; Fico, D.; Justice, N.J.; Zuloaga, D.G. Characterization and gonadal hormone regulation of a sexually dimorphic corticotropin-releasing factor receptor 1 cell group. J. Comp. Neurol. 2019, 527, 1056-1069. [CrossRef] 
42. O'Donnell, T.; Hegadoren, K.M.; Coupland, N.C. Noradrenergic mechanisms in the pathophysiology of posttraumatic stress disorder. Neuropsychobiology 2004, 50, 273-283. [CrossRef]

43. Grafe, L.A.; Bhatnagar, S. Orexins and stress. Front. Neuroendocrinol. 2018, 51, 132-145. [CrossRef]

44. Porkka-Heiskanen, T.; Kalinchuk, A.; Alanko, L.; Huhtaniemi, I.; Stenberg, D. Orexin A and B levels in the hypothalamus of female rats: The effects of the estrous cycle and age. Eur. J. Endocrinol. 2004, 150, 737-742. [CrossRef]

45. Messina, G.; Di Bernardo, G.; Viggiano, A.; De Luca, V.; Monda, V.; Messina, A.; Chieffi, S.; Galderisi, U.; Monda, M. Exercise increases the level of plasma orexin A in humans. J. Basic Clin. Physiol. Pharmacol. 2016, 27, 611-616. [CrossRef]

46. Winsky-Sommerer, R.; Boutrel, B.; de Lecea, L. Stress and arousal: The corticotrophin-releasing factor/hypocretin circuitry. Mol. Neurobiol. 2005, 32, 285-294. [CrossRef]

47. Sakurai, T.; Amemiya, A.; Ishii, M.; Matsuzaki, I.; Chemelli, R.M.; Tanaka, H.; Williams, S.C.; Richardson, J.A.; Kozlowski, G.P.; Wilson, S.; et al. Orexins and orexin receptors: A family of hypothalamic neuropeptides and G protein-coupled receptors that regulate feeding behavior. Cell 1998, 92, 573-585. [CrossRef]

48. Marcus, J.N.; Aschkenasi, C.J.; Lee, C.E.; Chemelli, R.M.; Saper, C.B.; Yanagisawa, M.; Elmquist, J.K. Differential expression of orexin receptors 1 and 2 in the rat brain. J. Comp. Neurol. 2001, 435, 6-25. [CrossRef]

49. Choi, D.L.; Davis, J.F.; Fitzgerald, M.E.; Benoit, S.C. The role of orexin-A in food motivation, reward-based feeding behavior and food-induced neuronal activation in rats. Neuroscience 2010, 167, 11-20. [CrossRef]

50. Mavanji, V.; Butterick, T.A.; Duffy, C.M.; Nixon, J.P.; Billington, C.J.; Kotz, C.M. Orexin/hypocretin treatment restores hippocampal-dependent memory in orexin-deficient mice. Neurobiol. Learn. Mem. 2017, 146, 21-30. [CrossRef]

51. Johnson, P.L.; Molosh, A.; Fitz, S.D.; Truitt, W.A.; Shekhar, A. Orexin, stress, and anxiety/panic states. Prog. Brain Res. 2012, 198, 133-161.

52. Shi, L.; Chen, W.; Deng, J.; Chen, S.; Han, Y.; Khan, M.Z.; Liu, J.; Que, J.; Bao, Y.; Lu, L.; et al. Orexin A Differentially Influences the Extinction Retention of Recent and Remote Fear Memory. Front. Neurosci. 2018, 12, 295. [CrossRef]

53. Flores, Á.; Valls-Comamala, V.; Costa, G.; Saravia, R.; Maldonado, R.; Berrendero, F. The hypocretin/orexin system mediates the extinction of fear memories. Neuropsychopharmacology 2014, 39, 2732-2741. [CrossRef]

54. Grafe, L.A.; Bhatnagar, S. The contribution of orexins to sex differences in the stress response. Brain Res. 2020, $1731,145893$. [CrossRef]

55. Grafe, L.A.; Cornfeld, A.; Luz, S.; Valentino, R.; Bhatnagar, S. Orexins Mediate Sex Differences in the Stress Response and in Cognitive Flexibility. Biol. Psychiatry 2017, 81, 683-692. [CrossRef]

56. Wang, J.B.; Murata, T.; Narita, K.; Honda, K.; Higuchi, T. Variation in the expression of orexin and orexin receptors in the rat hypothalamus during the estrous cycle, pregnancy, parturition, and lactation. Endocrine 2003, 22, 127-134. [CrossRef]

57. Nixon, J.P.; Mavanji, V.; Butterick, T.A.; Billington, C.J.; Kotz, C.M.; Teske, J.A. Sleep disorders, obesity, and aging: The role of orexin. Ageing Res. Rev. 2015, 20, 63-73. [CrossRef]

58. Loewen, S.P.; Paterson, A.R.; Loh, S.Y.; Rogers, M.F.; Hindmarch, C.C.T.; Murphy, D.; Ferguson, A.V. Sex-specific differences in cardiovascular and metabolic hormones with integrated signalling in the paraventricular nucleus of the hypothalamus. Exp. Physiol. 2017, 102, 1373-1379. [CrossRef]

59. López, M.; Señarís, R.; Gallego, R.; García-Caballero, T.; Lago, F.; Seoane, L.; Casanueva, F.; Diéguez, C. Orexin receptors are expressed in the adrenal medulla of the rat. Endocrinology 1999, 140, 5991-5994. [CrossRef]

60. Mazzocchi, G.; Malendowicz, L.K.; Gottardo, L.; Aragona, F.; Nussdorfer, G.G. Orexin A stimulates cortisol secretion from human adrenocortical cells through activation of the adenylate cyclase-dependent signaling cascade. J. Clin. Endocrinol. Metab. 2001, 86, 778-782. [CrossRef]

61. Ziolkowska, A.; Spinazzi, R.; Albertin, G.; Nowak, M.; Malendowicz, L.K.; Tortorella, C.; Nussdorfer, G.G. Orexins stimulate glucocorticoid secretion from cultured rat and human adrenocortical cells, exclusively acting via the OX1 receptor. J. Steroid Biochem. Mol. Biol. 2005, 96, 423-429. [CrossRef] [PubMed]

62. Lu, J.; Zhao, J.; Balesar, R.; Fronczek, R.; Zhu, Q.B.; Wu, X.Y.; Hu, S.H.; Bao, A.M.; Swaab, D.F. Sexually Dimorphic Changes of Hypocretin (Orexin) in Depression. EBioMedicine 2017, 18, 311-319. [CrossRef] [PubMed]

63. Cardoso, C.; Kingdon, D.; Ellenbogen, M.A. A meta-analytic review of the impact of intranasal oxytocin administration on cortisol concentrations during laboratory tasks: Moderation by method and mental health. Psychoneuroendocrinology 2014, 49, 161-170. [CrossRef] [PubMed]

64. Carter, C.; Kenkel, W.M.S.; MacLean, E.L.; Wilson, S.R.; Perkeybile, A.M.; Yee, J.R.; Ferris, C.F.; Nazarloo, H.P.; Porges, S.W.; Davis, J.M.; et al. Is Oxytocin "Nature's Medicine"? Pharmacol. Rev. 2020, 72, 829-861. [CrossRef]

65. Dabrowska, J.; Hazra, R.; Ahern, T.H.; Guo, J.D.; McDonald, A.J.; Mascagni, F.; Muller, J.F.; Young, L.J.; Rainnie, D.G. Neuroanatomical evidence for reciprocal regulation of the corticotrophin-releasing factor and oxytocin systems in the hypothalamus and the bed nucleus of the stria terminalis of the rat: Implications for balancing stress and affect. Psychoneuroendocrinology 2011, 36, 1312-1326. [CrossRef]

66. Huber, D.; Veinante, P.; Stoop, R. Vasopressin and oxytocin excite distinct neuronal populations in the central amygdala. Science 2005, 308, 245-248. [CrossRef]

67. Viviani, D.; Charlet, A.; van den Burg, E.; Robinet, C.; Hurni, N.; Abatis, M.; Magara, F.; Stoop, R. Oxytocin selectively gates fear responses through distinct outputs from the central amygdala. Science 2011, 333, 104-107. [CrossRef] 
68. Meinlschmidt, G.; Heim, C. Sensitivity to intranasal oxytocin in adult men with early parental separation. Biol. Psychiatry 2007, 61, 1109-1111. [CrossRef]

69. Ozbay, F.; Fitterling, H.; Charney, D.; Southwick, S. Social support and resilience to stress across the life span: A neurobiologic framework. Curr. Psychiatry Rep. 2008, 10, 304-310. [CrossRef]

70. Carmassi, C.; Marazziti, D.; Mucci, F.; Della Vecchia, A.; Barberi, F.M.; Baroni, S.; Giannaccini, G.; Palego, L.; Massimetti, G.; Dell'Osso, L. Decreased Plasma Oxytocin Levels in Patients With PTSD. Front. Psychol. 2021, 12, 612338. [CrossRef]

71. Donadon, M.F.; Martin-Santos, R.; Osório, F.L. The Associations between Oxytocin and Trauma in Humans: A Systematic Review. Front. Pharmacol. 2018, 9, 154. [CrossRef]

72. Frijling, J.L. Preventing PTSD with oxytocin: Effects of oxytocin administration on fear neurocircuitry and PTSD symptom development in recently trauma-exposed individuals. Eur. J. Psychotraumatol. 2017, 8, 1302652. [CrossRef]

73. Palgi, S.; Klein, E.; Shamay-Tsoory, S. The role of oxytocin in empathy in PTSD. Psychol. Trauma 2017, 9, 70-75. [CrossRef]

74. Uhl-Bronner, S.; Waltisperger, E.; Martínez-Lorenzana, G.; Condes, L.M.; Freund-Mercier, M.J. Sexually dimorphic expression of oxytocin binding sites in forebrain and spinal cord of the rat. Neuroscience 2005, 135, 147-154. [CrossRef]

75. Dumais, K.M.; Veenema, A.H. Vasopressin and oxytocin receptor systems in the brain: Sex differences and sex-specific regulation of social behavior. Front. Neuroendocrinol. 2016, 40, 1-23. [CrossRef]

76. Richard, S.; Zingg, H.H. The human oxytocin gene promoter is regulated by estrogens. J. Biol. Chem. 1990, 265, 6098-6103. [CrossRef]

77. Teicher, M.H.; Andersen, S.L.; Polcari, A.; Anderson, C.M.; Navalta, C.P. Developmental neurobiology of childhood stress and trauma. Psychiatr. Clin. N. Am. 2002, 25, 397-426. [CrossRef]

78. Wigger, A.; Neumann, I.D. Periodic maternal deprivation induces gender-dependent alterations in behavioral and neuroendocrine responses to emotional stress in adult rats. Physiol. Behav. 1999, 66, 293-302. [CrossRef]

79. Williams, T.D.; Carter, D.A.; Lightman, S.L. Sexual dimorphism in the posterior pituitary response to stress in the rat. Endocrinology 1985, 116, 738-740. [CrossRef]

80. Young, L.J.; Muns, S.; Wang, Z.; Insel, T.R. Changes in oxytocin receptor mRNA in rat brain during pregnancy and the effects of estrogen and interleukin 6. J. Neuroendocrinol. 1997, 9, 859-865. [CrossRef]

81. Britton, K.T.; Akwa, Y.; Spina, M.G.; Koob, G.F. Neuropeptide Y blocks anxiogenic-like behavioral action of corticotropin-releasing factor in an operant conflict test and elevated plus maze. Peptides 2000, 21, 37-44. [CrossRef]

82. Sabban, E.L.; Laukova, M.; Alaluf, L.G.; Olsson, E.; Serova, L.I. Locus coeruleus response to single-prolonged stress and early intervention with intranasal neuropeptide Y. J. Neurochem. 2015, 135, 975-986. [CrossRef]

83. Alpár, A.; Harkany, T. Orexin neurons use endocannabinoids to break obesity-induced inhibition. Proc. Natl. Acad. Sci. USA 2013, 110, 9625-9626. [CrossRef]

84. Shiozaki, K.; Kawabe, M.; Karasuyama, K.; Kurachi, T.; Hayashi, A.; Ataka, K.; Iwai, H.; Takeno, H.; Hayasaka, O.; Kotani, T.; et al. Neuropeptide Y deficiency induces anxiety-like behaviours in zebrafish (Danio rerio). Sci. Rep. 2020, 10, 5913. [CrossRef]

85. Tural, U.; Iosifescu, D.V. Neuropeptide Y in PTSD, MDD, and chronic stress: A systematic review and meta-analysis. J. Neurosci. Res. 2020, 98, 950-963. [CrossRef]

86. Lach, G.; de Lima, T.C. Role of NPY Y1 receptor on acquisition, consolidation and extinction on contextual fear conditioning: Dissociation between anxiety, locomotion and non-emotional memory behavior. Neurobiol. Learn. Mem. 2013, 103, 26-33. [CrossRef]

87. Michel, M.C.; Lewejohann, K.; Farke, W.; Bischoff, A.; Feth, F.; Rascher, W. Regulation of NPY/NPY Y1 receptor/G protein system in rat brain cortex. Am. J. Physiol. 1995, 268, R192-R200. [CrossRef] [PubMed]

88. Nahvi, R.J.; Nwokafor, C.; Serova, L.I.; Sabban, E.L. Single Prolonged Stress as a Prospective Model for Posttraumatic Stress Disorder in Females. Front. Behav. Neurosci. 2019, 13, 17. [CrossRef] [PubMed]

89. Eva, C.; Serra, M.; Mele, P.; Panzica, G.; Oberto, A. Physiology and gene regulation of the brain NPY Y1 receptor. Front. Neuroendocrinol. 2006, 27, 308-339. [CrossRef] [PubMed]

90. Martini, M.; Sica, M.; Gotti, S.; Eva, C.; Panzica, G.C. Effects of estrous cycle and sex on the expression of neuropeptide Y Y1 receptor in discrete hypothalamic and limbic nuclei of transgenic mice. Peptides 2011, 32, 1330-1334. [CrossRef] [PubMed]

91. Ditlevsen, D.N.; Elklit, A. The combined effect of gender and age on post-traumatic stress disorder: Do men and women show differences in the lifespan distribution of the disorder? Ann. Gen. Psychiatry 2010, 9, 32. [CrossRef]

92. Acosta-Martinez, M.; Horton, T.; Levine, J.E. Estrogen receptors in neuropeptide Y neurons: At the crossroads of feeding and reproduction. Trends Endocrinol. Metab. 2007, 18, 48-50. [CrossRef]

93. Skórzewska, A.; Lehner, M.; Wisłowska-Stanek, A.; Turzyńska, D.; Sobolewska, A.; Krząścik, P.; Szyndler, J.; Maciejak, P.; Chmielewska, N.; Kołosowska, K.; et al. Individual susceptibility or resistance to posttraumatic stress disorder-like behaviours. Behav. Brain Res. 2020, 386, 112591. [CrossRef]

94. De Souza, E.B. Corticotropin-releasing factor receptors: Physiology, pharmacology, biochemistry and role in central nervous system and immune disorders. Psychoneuroendocrinology 1995, 20, 789-819. [CrossRef]

95. Matchett, B.J.; Grinberg, L.T.; Theofilas, P.; Murray, M.E. The mechanistic link between selective vulnerability of the locus coeruleus and neurodegeneration in Alzheimer's disease. Acta Neuropathol. 2021, 141, 631-650. [CrossRef]

96. Haas, D.A.; George, S.R. Neuropeptide Y-induced effects on hypothalamic corticotropin-releasing factor content and release are dependent on noradrenergic/adrenergic neurotransmission. Brain Res. 1989, 498, 333-338. [CrossRef] 
97. Maejima, Y.; Takahashi, S.; Takasu, K.; Takenoshita, S.; Ueta, Y.; Shimomura, K. Orexin action on oxytocin neurons in the paraventricular nucleus of the hypothalamus. Neuroreport 2017, 28, 360-366. [CrossRef]

98. Wang, C.; Han, X.; Sun, X.; Guo, F.; Luan, X.; Xu, L. Orexin-A signaling in the paraventricular nucleus promote gastric acid secretion and gastric motility through the activation neuropeptide $Y$ Y1 receptors and modulated by the hypothalamic lateral area. Neuropeptides 2019, 74, 24-33. [CrossRef]

99. Parker, S.L.; Crowley, W.R. Central stimulation of oxytocin release in the lactating rat: Interaction of neuropeptide Y with alpha-1-adrenergic mechanisms. Endocrinology 1993, 132, 658-666. [CrossRef]

100. Smith, D. Epigenetics. In Encyclopedia of Clinical Neuropsychology; Kreutzer, J., DeLuca, J., Caplan, B., Eds.; Springer: Cham, Switzerland, 2017. [CrossRef]

101. Gray, J.D.; Kogan, J.F.; Marrocco, J.; McEwen, B.S. Genomic and epigenomic mechanisms of glucocorticoids in the brain. Nat. Rev. Endocrinol. 2017, 13, 661-673. [CrossRef]

102. Uddin, M.; Sipahi, L.; Li, J.; Koenen, K.C. Sex differences in DNA methylation may contribute to risk of PTSD and depression: A review of existing evidence. Depress. Anxiety 2013, 30, 1151-1160. [CrossRef]

103. Yehuda, R.; Bell, A.; Bierer, L.M.; Schmeidler, J. Maternal, not paternal, PTSD is related to increased risk for PTSD in offspring of Holocaust survivors. J. Psychiatr. Res. 2008, 42, 1104-1111. [CrossRef]

104. Pizzimenti, C.L.; Lattal, K.M. Epigenetics and memory: Causes, consequences and treatments for posttraumatic stress disorder and addiction. Genes Brain Behav. 2015, 14, 73-84. [CrossRef]

105. Murphy, C.P.; Singewald, N. Role of MicroRNAs in Anxiety and Anxiety-Related Disorders. Curr. Top Behav. Neurosci. 2019, 42, 185-219.

106. Higuchi, F.; Uchida, S.; Yamagata, H.; Abe-Higuchi, N.; Hobara, T.; Hara, K.; Kobayashi, A.; Shintaku, T.; Itoh, Y.; Suzuki, T.; et al. Hippocampal MicroRNA-124 Enhances Chronic Stress Resilience in Mice. J. Neurosci. 2016, 36, 7253-7267. [CrossRef]

107. Wang, S.S.; Mu, R.H.; Li, C.F.; Dong, S.Q.; Geng, D.; Liu, Q.; Yi, L.T. microRNA-124 targets glucocorticoid receptor and is involved in depression-like behaviors. Prog. Neuropsychopharmacol. Biol. Psychiatry 2017, 79, 417-425. [CrossRef]

108. Balakathiresan, N.S.; Chandran, R.; Bhomia, M.; Jia, M.; Li, H.; Maheshwari, R.K. Serum and amygdala microRNA signatures of posttraumatic stress: Fear correlation and biomarker potential. J. Psychiatr. Res. 2014, 57, 65-73. [CrossRef]

109. Linnstaedt, S.D.; Rueckeis, C.A.; Riker, K.D.; Pan, Y.; Wu, A.; Yu, S.; Wanstrath, B.; Gonzalez, M.; Harmon, E.; Green, P.; et al. MicroRNA-19b predicts widespread pain and posttraumatic stress symptom risk in a sex-dependent manner following trauma exposure. Pain 2020, 161, 47-60. [CrossRef]

110. Wang, X.; Sundquist, K.; Hedelius, A.; Palmér, K.; Memon, A.A.; Sundquist, J. Circulating microRNA-144-5p is associated with depressive disorders. Clin. Epigenet. 2015, 7, 69. [CrossRef]

111. Snijders, C.; de Nijs, L.; Baker, D.G.; Hauger, R.L.; van den Hove, D.; Kenis, G.; Nievergelt, C.M.; Boks, M.P.; Vermetten, E.; Gage, F.H.; et al. MicroRNAs in Post-traumatic Stress Disorder. Curr. Top Behav. Neurosci. 2018, 38, $23-46$.

112. Myers, K.M.; Davis, M. Mechanisms of fear extinction. Mol. Psychiatry 2007, 12, 120-150. [CrossRef] [PubMed]

113. Myers, K.M.; Ressler, K.J.; Davis, M. Different mechanisms of fear extinction dependent on length of time since fear acquisition. Learn. Mem. 2006, 13, 216-223. [CrossRef] [PubMed]

114. Bangasser, D.A.; Valentino, R.J. Sex differences in stress-related psychiatric disorders: Neurobiological perspectives. Front. Neuroendocrinol. 2014, 35, 303-319. [CrossRef] [PubMed]

115. Milligan-Saville, J.S.; Graham, B.M. Mothers do it differently: Reproductive experience alters fear extinction in female rats and women. Transl. Psychiatry 2016, 6, e928. [CrossRef]

116. Tang, S.; Graham, B.M. Hormonal, reproductive, and behavioural predictors of fear extinction recall in female rats. Horm. Behav. 2020, 121, 104693. [CrossRef]

117. Goldstein, J.M.; Jerram, M.; Abbs, B.; Whitfield-Gabrieli, S.; Makris, N. Sex differences in stress response circuitry activation dependent on female hormonal cycle. J. Neurosci. 2010, 30, 431-438. [CrossRef]

118. Chang, Y.J.; Yang, C.H.; Liang, Y.C.; Yeh, C.M.; Huang, C.C.; Hsu, K.S. Estrogen modulates sexually dimorphic contextual fear extinction in rats through estrogen receptor beta. Hippocampus 2009, 19, 1142-1150. [CrossRef]

119. Glover, E.M.; Jovanovic, T.; Mercer, K.B.; Kerley, K.; Bradley, B.; Ressler, K.J.; Norrholm, S.D. Estrogen levels are associated with extinction deficits in women with posttraumatic stress disorder. Biol. Psychiatry 2012, 72, 19-24. [CrossRef]

120. Parrish, J.N.; Bertholomey, M.L.; Pang, H.W.; Speth, R.C.; Torregrossa, M.M. Estradiol modulation of the renin-angiotensin system and the regulation of fear extinction. Transl. Psychiatry 2019, 9, 36. [CrossRef]

121. Akiki, T.J.; Abdallah, C.G. Are There Effective Psychopharmacologic Treatments for PTSD? J. Clin. Psychiatry 2018, 80, 18ac12473. [CrossRef]

122. Tural, U.; Iosifescu, D.V. The Prevalence of Mitral Valve Prolapse in Panic Disorder: A Meta-Analysis. Psychosomatics 2019, 60, 393-401. [CrossRef]

123. Sayed, S.; Van Dam, N.T.; Horn, S.R.; Kautz, M.M.; Parides, M.; Costi, S.; Collins, K.A.; Iacoviello, B.; Iosifescu, D.V.; Mathé, A.A.; et al. A Randomised Dose-Ranging Study of Neuropeptide Y in Patients with Posttraumatic Stress Disorder. Int. J. Neuropsychopharmacol. 2018, 21, 3-11. [CrossRef]

124. Itani, O.; Jike, M.; Watanabe, N.; Kaneita, Y. Short sleep duration and health outcomes: A systematic review, meta-analysis, and meta-regression. Sleep Med. 2017, 32, 246-256. [CrossRef] 
125. Kobayashi, I.; Howell, M.K. Impact of Traumatic Stress on Sleep and Management Options in Women. Sleep Med. Clin. 2018, 13, 419-431. [CrossRef]

126. Difede, J.; Cukor, J.; Wyka, K.; Olden, M.; Hoffman, H.; Lee, F.S.; Altemus, M. D-cycloserine augmentation of exposure therapy for posttraumatic stress disorder: A pilot randomised clinical trial. Neuropsychopharmacology 2014, 39, 1052-1058. [CrossRef] 